\title{
First report of Pythiogeton ramosum (Pythiales) in Australia
}

\author{
Duy Phu Le • Mike Smith • Elizabeth Aitken
}

Received: 8 January 2014 / Accepted: 20 March 2014 / Published online: 30 March 2014

(C) Australasian Plant Pathology Society Inc. 2014

\begin{abstract}
In 2012, a project was initiated to assess if the soft rot disease of ginger in Australian fields was associated with pathogens other than Pythium myriotylum. Together with nine Pythium spp., ten isolates of a Pythium-like organism were also recovered from ginger with soft rot symptoms. These Pythium-like isolates were identified as Pythiogeton (Py.) ramosum based on its morphology and ITS sequences. In-vitro pathogenicity tests allowed confirmation of pathogenicity of Py. ramosum on excised carrot (Daucus carota), sweet potato (Ipomoea batatas) and potato (Solanum tubersum) tubers, although it was not pathogenic on excised ginger (Zingiber officinale) and radish (Raphanus sativus) rhizome/roots. In addition it was found to be pathogenic on bean (Phaseolus vulgaris), capsicum (Capsicum annuum) and cauliflower (Brassica oleracea var. botrytis) seedlings. This is the first record of Py. ramosum and its pathogenicity in Australia.
\end{abstract}

Keywords Ginger rhizome $\cdot$ Zingiber officinale $\cdot$ Pythium soft rot

The Australian ginger industry is small (less than $1 \%$ contribution to world production), but it is a cash crop for around 30 full time growers, who produce approximately AUD 15.6 million at farm gate value per year (Camacho and Brescia 2009). The annual production of the whole Australian ginger industry is estimated at about 8,000 tonnes with almost half of this delivered to the domestic fresh market and the rest for the processing industry (Camacho and Brescia 2009). In 2007, farmers unexpectedly experienced severe losses (up to $100 \%$

D. P. Le $(\bowtie) \cdot$ E. Aitken

School of Agriculture and Food Sciences, The University of Queensland, Brisbane 4072, Australia

e-mail: p.le@uq.edu.au

M. Smith

Queensland Department of Agriculture, Fisheries and Forestry,

Maroochy Research Station, Nambour 4560, Australia in some ginger fields) due to Pythium Soft Rot (PSR). In 2009, Pythium myriotylum was reported as a causal agent responsible for the outbreak in Australia (Stirling et al. 2009). However, from our recent research, it is proposed that there is probably more than one Pythium sp. associated with PSR of ginger in Australian fields. In 2012, ginger with PSR symptoms caused by Pythium spp. was sampled from a representative selection of farms at Yandina, on the Sunshine Coast, Queensland, Australia. Along with nine Pythium spp. isolated from PSR ginger and soil around the ginger rhizome, ten isolates of a Pythium-like organism were also obtained from PSR ginger sampled from two farms (farm 1 at $26^{\circ} 32^{\prime} \mathrm{S}, 152^{\circ} 56^{\prime} \mathrm{E}$ and farm 2 at $26^{\circ}$ $\left.33^{\prime} \mathrm{S}, 152^{\circ} 56^{\prime} \mathrm{E}\right)$ at Yandina. Isolations had been undertaken by excising sections $\left(5 \mathrm{~mm}^{2}\right)$ of rhizome with PSR symptoms, quickly surface decontaminating (around $10 \mathrm{~s}$ ) with $25 \%$ bleach containing $1 \% \mathrm{HOCl}$, then washing twice with sterilized distilled water, blotted dry with autoclaved paper towel. The sections were then transferred on to Petri plates with corn meal agar with an amendment of $50 \mu \mathrm{g} / \mathrm{ml}$ Penicillin, $50 \mu \mathrm{g} / \mathrm{ml}$ Polymyxin, and $25 \mu \mathrm{g} / \mathrm{ml}$ Pirmaricin $(\mathrm{CMA}+3 \mathrm{P})$. The Petri plates were incubated in the dark overnight at $27{ }^{\circ} \mathrm{C}$, then sections taken from the growing edge of the colonies were transferred onto $1.5 \%$ water agar, incubated again under the same conditions for another night, after which hyphal tips of each of the isolates were excised out under an inverted compound microscope (Leica) and placed onto full strength potato dextrose agar (PDA Difco).

All ten Pythium-like isolates were considered to be heterothallic as attempts to produce sexual structures on dual cultures were not successful. Using the keys of Jee et al. (2000) and Huang et al. (2013), these isolates were then identified as Pythiogeton ramosum based on the typical features of sickleshape appressoria, terminal, subspherical, ellipsoidal, utriform, or bursiform sporangia with apical beaks (Fig. 1) which measured from 20-214× 18-48 $\mu \mathrm{m}$. Colonies on PDA and CMA media did not show any special pattern, mycelia 


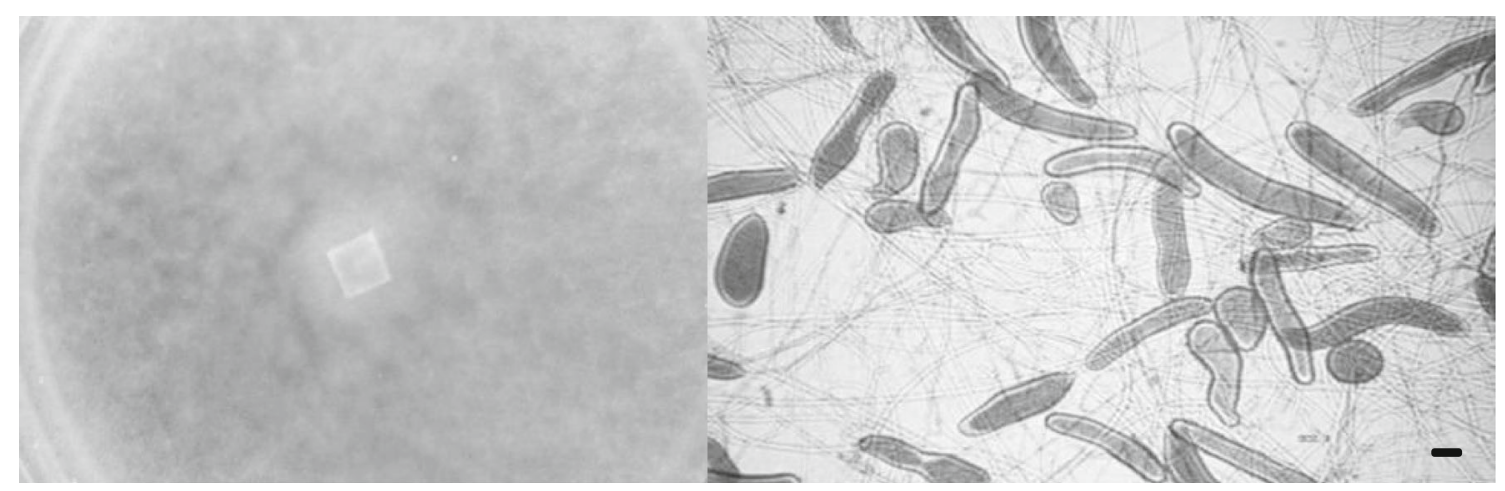

Fig. 1 Py. ramosum growing on PDA showing an indistinctive pattern (left), terminal bursiform sporangia with different sizes and shapes of globe and elongate $(r i g h t)(B a r=20 \mu m)$

were quite sparse on media and rarely aerial (Fig. 1). The hyphae were aseptate, hyaline, smooth, 2-5 (-7) $\mu \mathrm{m}$ wide. The hyphae also had many shorter branches which were usually bearing appressoria and growing at a right angle with the main hyphae. On solid culture media, old sporangia formed vacuoles, which had the potential to be misidentified as oospores. Two isolates of this species description were deposited with Queensland Plant Pathology Herbarium with BRIP numbers (BRIP59948 and BRIP59949). For confirmation of species identification, ITS regions were amplified and analysed. Pure DNA from the mycelial mats growing in potato broth was obtained using CTAB protocol (Doyle and Doyle 1990). A PCR reaction was carried out in a Eppendorf Mastercycler $^{\circledR}$ using the two universal primers ITS1 and ITS4 (White et al. 1990) to allow amplification (approximately $860 \mathrm{bp}$ ) of ITS the region including the $5.8 \mathrm{~S}$ rRNA encoding region. The Genbank database was searched (BLAST) for similar sequences resulting in $100 \%$ homology with a Py. ramosum isolate JQ610190.1 from Tawain (Huang et al. 2013). The sequences were also deposited with Genbank under KF151204 and KF151205.

Pythiogeton ramosum was first isolated from plant debris by Minden (1916) and was later commonly recovered from materials under anaerobic conditions (Czeczuga et al. 2005; El-Hissy et al. 1994; Huang et al. 2013; Nascimento et al. 2012). Py. ramosum is not well studied and was believed to be a saprophyte and until recently its pathogenicity on living plants had not been confirmed (Ann et al. 2006; Huang et al. 2013). In this study we initially attempted to carry out some in-vitro pathogenicity tests for our isolates to check if they were pathogenic on tested materials.

Pathogenicity tests were conducted in-vitro on ginger (Zingiber officinale), carrot (Daucus carota), radish (Raphanus sativus), sweet potato (Ipomoea batatas) and potato (Solanum tuberosum) rhizome/tubers. The experiment was based on descriptions of Le et al. (2010) to test the pathogenicity and extent of rotting from isolates (BRIP59948 and BRIP59949) inoculated on excised rhizome/tuber sections $(1 \times 1 \times 5.5 \mathrm{~cm})$ at $27^{\circ} \mathrm{C}$. All tested isolates of Py. ramosum were shown to be non-pathogenic on excised ginger and radish pieces, but they were pathogenic on carrot, sweet potato and potato tubers. The tested tubers were decayed, soft and brown in colour and Py. ramosum was reisolated after placing decayed tissue onto CMA+3P. Additionally, pre-emerging damping off tests were carried out in Petri plates according to descriptions of Zhang and Yang (2000) and disease indices (scale from 0 to 1 ) were calculated to evaluate aggressive levels of Py. ramosum on some vegetable crops including bean (Phaseolus vulgaris), capsicum (Capsicum annuum), and cauliflower (Brassica oleracea var.botrytis). Disease indices recorded from 0.13 to 0.50 indicated that $P y$. ramosum was able to attack and cause pre-emerging damping off on these crop species (Fig. 2). The results from this study allowed us to conclude that Py. ramosum is pathogenic on several hosts and this is the first report of the pathogenicity of Py. ramosum on either excised rhizome/tuber sections or seeds/seedlings of the tested materials. Although Py. ramosum was isolated directly from soft rot ginger, it was non-pathogenic on ginger at $27{ }^{\circ} \mathrm{C}$. Therefore, more pathogenicity tests including on living plants at different temperatures will be warranted.

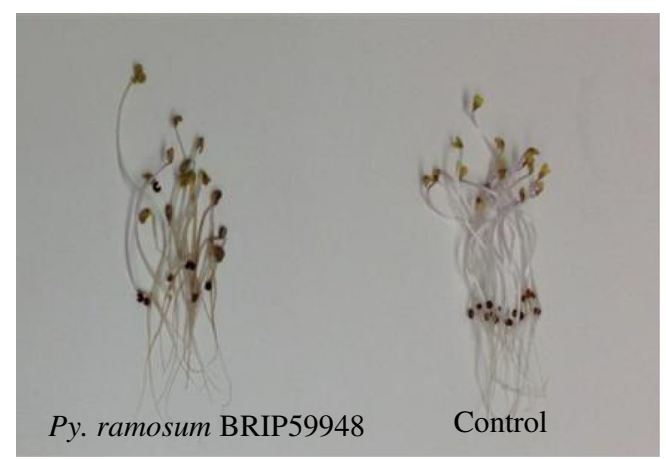

Fig. 2 Cauliflower seedlings following inoculation with Py. ramosum (left) showing necrosis, brown rot in comparison to white and healthy seedlings in the uninoculated controls (right) 
Acknowledgments This work is a part of Pythium spp. on ginger in Australia project funded by Rural Industries Research and Development Corporation (RIRDC). We greatly thank Mr. Jin-hsing Huang from Plant Pathology Division, Taiwan Agricultural Research Institute for technical consultation, Mr Rob Abbas from Rob Abbas Consulting Pty. Ltd. for sampling. The first author also wants to thank Endeavour Postgraduate Awards for rewarding the PhD scholarship.

\section{References}

Ann P-J, Huang J-H, Wang I-T, Ko W-H (2006) Pythiogeton zizaniae, a new species causing basal stalk rot of water bamboo in Taiwan. Mycologia 98:116-120

Camacho HE, Brescia A (2009) The Australian ginger industry: overview of market trends and oppotunities. Department of Employment, Economic Development and Innovation, The State of Queensland, Australia, p 54

Czeczuga B, Mazalska B, Godlewska A, Muszyńska E (2005) Aquatic fungi growing on dead fragments of submerged plants. Limnol Ecol Manag Inland Waters 35:283-297

Doyle JJ, Doyle JL (1990) Isolation of plant DNA from fresh tissue. Focus 12:13

El-Hissy F, Khallil AR, Ali E (1994) Aquatic phycomycetes from egyptian soil (Delta Region). Microbiol Res 149:271-282
Huang J-H, Chen C-Y, Lin Y-S, Ann P-J, Huang H-C, Chung W-H (2013) Six new species of Pythiogeton in Taiwan, with an account of the molecular phylogeny of this genus. Mycoscience 54:130 147

Jee HJ, Ho HH, Cho WD (2000) Pythiogeton zeae sp. nov. causing root and basal stalk rot of corn in Korea. Mycologia 92:522-527

Le PD, Smith MK, Aitken EAB (2010) Pythium spp. on ginger (zingiber officinale Roscoe) in Australia. In: Stirling GR (ed) Proceedings of the sixth Australasian soilborne diseases symposium. Twin Waters, Queensland, p 62. ISBN 978-0-646-53983-6

Minden MV (1916) Beitrage zur biologie und systematik einheimsche submerser Phycomyceten. Falk Mykolog Untersuch Berichte 2:146-255

Nascimento CA, Gomes EPC, Souza JID, Pires-Zottarelli CLA (2012) Zoosporic true fungi and heterotrophic straminipiles assemblages from soil of Brazilian Cerrado areas. Fungal Ecol 5:114-123

Stirling GR, Turaganivalu U, Stirling AM, Lomavatu MF, Smith MK (2009) Rhizome rot of ginger (Zingiber officinale) caused by Pythium myriotylum in Fiji and Australia. Australas Plant Pathol 38:453-460

White TJ, Bruns T, Lee S, Taylor J (1990) Amplification and direct sequencing of fungal ribosomal RNA genes for phylogenetics. In: Innis MA, Gelfand DH, Sninsky JJ, White TJ (eds) PCR protocols: a guide to methods and applications. Academic Press, Inc, California, pp 315-322

Zhang BQ, Yang XB (2000) Pathogenicity of Pythium populations from corn-soybean rotation fields. Plant Dis 84:94-99 